\title{
EVALUASI KEBIJAKAN PENGATURAN SISTIM BAGI HASIL (Kasus Implementasi Undang-undang Bagi Hasil (UUBH) No. 16/1964 pada Perikanan Rumpon di Kabupaten Badung, Bali) ${ }^{1}$
}

\author{
Rizky Muhartono, Ahmad Zamroni dan Zahri Nasution \\ Balai Besar Penelitian Sosial Ekonomi Kelautan dan Perikanan \\ JI. KS. Tubun Petamburan VI Jakarta 10260 \\ Telp. (021) 53650162, Fax. (021)53650159 \\ Email: rizky_san@yahoo.com
}

Diterima 18 Juli 2012 - Disetujui 23 November 2012

\begin{abstract}
ABSTRAK
Tulisan ini didasarkan pada hasil penelitian yang dilaksanakan di Desa Kedonganan, Kabupaten Badung, Bali. Tujuan penelitian ini adalah untuk melakukan evaluasi terhadap implementasi UU Bagi Hasil No. 16/1964. Pendekatan studi kasus diterapkan dalam penelitian ini. Data diperoleh melalui wawancara dengan responden yang dipilih berdasarkan metode purposive sampling. Responden yang terpilih merupakan nelayan rumpon yang telah bekerja minimal satu tahun. Mengacu pada pendekatan evaluasi kebijakan, analisis mencakup aspek materi, aspek implementasi dan aspek faktor penentu. Dari pendekatan analisis tersebut, diperoleh kesimpulan-kesimpulan sebagai berikut: Pertama, teridentifikasi adanya ketidaksesuaian penerapan UU di lapangan, antara lain dalam hal besaran proporsi, beban tanggungan, dan jangka waktu perjanjian; Kedua, kelemahan yang menyebabkan penyimpangan tersebut, terjadi baik pada aspek materi maupun implementasi. Pada aspek materi, ditemukan bahwa produk hukum tersebut tidak selaras dengan kondisi lokal, termasuk adat setempat. Sementara itu, pada aspek implementasi, produk hukum tersebut tidak berjalan baik karena keterbatasan informasi, ketiadaan ruang untuk modifikasi, dan ketiadaan lembaga kontrol yang secara efektif mengawal pelaksanaannya. Rekomendasi yang dirumuskan berdasarkan hasil penelitian ini adalah: (1) Beberapa pasal UU 16/1964 sebaiknya disempurnakan, yaitu yang menyangkut bagian pemilik modal, biaya penyusutan aset, dan umur ekonomis aset produksi dalam perhitungan bagi hasil; (2) Perlu diberikan mandat khusus kepada sebuah lembaga yang untuk melakukan pengawalan implementasi UU sehingga efektivitas UU dapat ditingkatkan; (3) Perlu disusun sebuah naskah akademis yang dikembangkan berdasarkan perluasan cakupan kajian ini, yang digunakan untuk mendorong penyempurnaan $\mathrm{UU}$, sehingga selaras dengan kondisi saat ini, demi perkembangan perikanan yang lebih baik.
\end{abstract}

Kata Kunci: : evaluasi kebijakan, bagi hasil, perikanan rumpon, Kedonganan, Bali

Abstract: Evaluation of Policy on Benefit Shareing Systim (A case study on Implementation of Law 16/1964 in Rumpon Fishery of Badung Regency, Bali). By: Rizky Muhartono, Ahmad Zamroni and Zahri Nasution.

This paper was based on the results of research conducted at Kedonganan, Badung Regency, Bali. Purpose of the research is to evaluate the implementation of Benefit Sharing System Regulation No. 16/1964. Case study approach was adopted in this research. Data were obtained through interviews with selected respondents based on purposive sampling method. In this case, the rumpon fishers selected as respondent who has worked at least one year. Referring to the policy evaluation approach, the

${ }^{1}$ Tulisan ini sudah dipresentasikan pada Temu Karya Ilmiah Riset Kelautan dan Perikanan di Jakarta 22-23 Oktober 2007. Kegiatan ini diselenggarakan oleh Badan Riset Kelautan dan Perikanan-Departemen Kelautan dan Perikanan 
analyses covered three components: material, implementation, and factor aspects. Results showed the following: firstly, it was identified that that several applications deviated from those directed by the law. These included the proportion scheme, burden sharing and contract tenure. Secondly, it was observed that imperfection causing these deviations occurred in both the material and implementation aspects. Regarding material aspects, it was found that this legal product was incompatible with local conditions, including local traditions/customs. Meanwhile, concerning the implementation aspect, the law was found ineffective due to lacks of information, room for modification and effective control institution. In line with these findings, it is recommended that: (1) Several articles of the law, namely those related to the the share of capital owners, depreciation, and productive assets economic age should be refined; (2) A certain mandate should be granted to an institution so as that implementation can be carried out effectively, and (3) A study extending from these findings should be carried out to result in a white book aimed at revisiting the law, for the sake of better fishery development.

\section{Keywords: policy evaluation, benefit share, rumpon fishery, Kedonganan, Bali}

\section{PENDAHULUAN}

Setidaknya terdapat 119.837 unit kapal (in board) yang terdiri dari berbagai ukuran terlibat dalam kegiatan penangkapan ikan di laut (Anonimous 2006). Jumlah tersebut mengisyaratkan besarnya peran yang dimainkan oleh nelayan yang mengawaki kapal-kapal tersebut terhadap perkembangan perikanan, khususnya perikanan tangkap. Nelayan-nelayan ini memiliki peran sebagai ujung tombak kegiatan penangkapan dan pada akhirnya menentukan kuantitas serta kualitas ikan yang didaratkan. Pada posisi seperti itu, insentif yang diterima oleh nelayan menjadi suatu hal yang sangat penting untuk mendapatkan perhatian. Apabila insentif yang diterima cukup tinggi, maka motivasi yang dimiliki akan besar untuk melakukan yang terbaik. Sebaliknya, apabila insentif yang didapatkan terlalu kecil, maka dengan sendirinya produksi yang dihasilkan tidak akan maksimal, baik dalam hal kualitas maupun kuantitasnya.

Salah satu bentuk insentif bagi nelayan adalah pendapatan yang mereka peroleh dari kegiatan penangkapan, yang pada kenyataannya sangat dipengaruhi oleh sistem bagi hasil yang berlaku. Jika sistem bagi hasil menguntungkan semua pihak (pemilik modal dan pekerja /ABK), maka pendapatan yang diperoleh masingmasing akan menjadi wajar sesuai dengan perannya masing-masing. Selanjutnya, apabila hal ini dapat terwujud, maka motivasi dari masing-masing pelaku usaha penangkapan tersebut akan semakin besar. Implikasinya, kesejahteraan nelayan dapat diharapkan akan membaik, ketersediaan ikan berkualitas akan meningkat dan kinerja perikanan secara umum dapat diperbaiki.

Undang-undang yang mengatur bagi hasil perikanan di Indonesia telah tersedia, namun perannya masih jauh dari yang diharapkan. Dari hasil penelusuran literatur, peraturan yang terkait dengan mekanisme bagi hasil telah berumur lebih dari 40 tahun dan dianggap tidak dapat mengakomodasikan kepentingan dan kondisi saat ini. Pengaturan tersebut adalah yang tertuang dalam Undang-Undang No.16 Tahun 1964. Perkembangan kondisi sosial, ekonomi maupun budaya telah membuat pelaksanaan undang-undang ini terhambat dan tidak maksimal perannya.

Diduga bahwa tidak ada satu pun kegiatan penangkapan yang menerapkan aspek-aspek sebagaimana dimaksud oleh Undang-Undang No.16 Tahun 1964. Kalaupun ada, aspek-aspek tersebut hanya merupakan sebagian dari kandungan undang-undang, yaitu aspek-aspek yang dianggap selaras dengan kondisi lokal. Dalam praktek di bidang hukum, hal seperti itu sebenarnya merupakan sesuatu yang normal; sebagaimana dikatakan oleh Soekanto dalam Herwening (1983), ada fenomena bahwa berbagai peraturan perundang-undangan yang masih berlaku 
yuridis formal dapat saja dianggap tidak sesuai dengan kondisi masyarakat, tidak adil dan sebagainya. Fenomena seperti ini semestinya mendapatkan mendapatkan perhatian dan kita gunakan untuk menyikapi kondisi kurang berperannya undang-undang bagi hasil yang telah berumur lebih 40 tahun tersebut. Besar kemungkinan bahwa perbaikan-perbaikan memang sudah saatnya dilakukan sehingga undang-undang tersebut dapat sesuai dengan tuntutan jaman.

Ada berbagai aspek yang dapat dijadikan acuan dalam melakukan perbaikan UU. Selain aspek sosial, ekonomi dan budaya, aspekaspek lain yang juga harus dipertimbangkan adalah aspek teknis, aspek politis, persepsi, dan berbagai aspek lain yang relevan dengan kondisi sekarang. Misalnya adalah masalah keadilan yang dipengaruhi oleh persepsi masing-masing pihak. Walaupun dari segi ekonomi sebuah sistem pembagian hasil dipandang tidak adil dari kacamata tertentu, ada kemungkinan bahwa sudut pandang lain tidak melihatnya demikian. Salah satu contohnya adalah apabila hal tersebut juga dilatarbelakangi oleh pandangan adat. Hadikusumah dalam Herwening (1983) menyatakan bahwa hukum adat itu bersifat turun temurun dan diperhatikan serta dihormati. Dengan demikian, apabila hukum adat masih berlaku, maka hukum formal harus juga dibuat dengan memperhatikan prinsipprinsipnya. Contoh tersebut hanyalah sebagian dari aspek yang perhatikan dalam perbaikan UU Bagi hasil.

Penulisan makalah ini dimaksudkan untuk melakukan evaluasi terhadap kebijakan pengaturan bagi hasil sebagaimana dituangkan dalam UU 16/1964. Evaluasi kebijakaan tersebut adalah bagian dari siklus kebijakan, yang terdiri dari empat tahapan, yaitu: perumusan masalah, implementasi, evaluasi dan perbaikan kebijakan atau pembatalan kebijakan. Dengan demikian, berdasarkan evaluasi tersebut, diharapkan dapat memberikan rekomendasi yang terkait dengan keberadaan UU tersebut.

\section{METODOLOGI}

\section{Pendekatan Penelitian dan Kerangka Konseptual:}

Penelitian ini dilakukan dengan pendekatan evaluasi kebijakan (Mustopadidjaja, 2003) dan studi kasus (Nazir, 1988). Evaluasi kebijakaan tersebut adalah bagian dari siklus kebijakan, yang terdiri dari empat tahapan, yaitu: perumusan masalah, implementasi, evaluasi dan perbaikan kebijakan atau pembatalan kebijakan. Kasus nelayan rumpon di Desa Kedonganan, Badung, Bali diambil sebagai kasus contoh dengan harapan bahwa kasus tersebut dapat membuka wacana untuk melakukan kegiatan penelitian dengan cakupan yang lebih besar. Berdasarkan evaluasi tersebut, diharapkan dapat memberikan rekomendasi yang terkait dengan keberadaan UU tersebut. Secara diagramatis, kerangka konseptual dari penelitian ini, yang didasarkan pada pendekatan tersebut dapat dilihat dari Gambar 1.

\section{Waktu dan Lokasi Penelitian}

Penelitian dilakukan pada bulan Juni tahun 2006 dan mengambil lokasi di Desa Kedonganan, Kabupaten Badung, Propinsi Bali. Lokasi ini dipilih karena merupakan tempat pendaratan ikan skala rakyat.

\section{Jenis dan Sumber Data}

Data yang diambil meliputi data primer dan sekunder. Data primer diperoleh dari wawancara dan hasil observasi langsung di lapang. Sementara itu, data sekunder diperoleh dari studi literatur maupun penggalian dokumen di instansi-instansi terkait, seperti: Tempat Pendaratan Ikan Kedonganan, Dinas Perikanan, dan lain lain.

Data primer dikumpulkan melalui pendekatan purposive sampling (Singarimbun dan Effendi, 1985), dimana informan adalah 7 (tujuh) unit perikanan rumpon yang telah melakukan usahanya selama satu tahun atau lebih. Pengambilan informasi dilakukan dengan 
wawancara mendalam (indepth interview) menggunakan alat bantu berupa kuesioner. Informan ditentukan melalui subgrup dari populasi sedemikian rupa sehingga mempunyai sifat-sifat yang sesuai dengan populasi.

\section{Metode Analisis Data}

Mengacu pada pendekatan evaluasi kebijakan, analisis mencakup aspek materi, aspek implementasi dan aspek faktor penentu. Untuk itu, data yang diperoleh dikelompokkan, dianalisis dan ditampilkan secara deskriptif kualitatif (Nazir, 1988). Analisis dilakukan dengan cara membandingkan kondisi objektif (pelaksanaan bagi hasil di lapang) dengan poin-poin seperti dimaksud dalam UUBH No.16 Tahun 1964. Faktor penghambat pelaksanaan UUBH No.16 Tahun 1964 diidentifikasi untuk mendapatkan kesimpulan tentang hal-hal yang harus dilakukan terhadap UU tersebut.

\section{KONDISI LINGKUNGAN PENERAPAN UU 16/1964 DI KEDONGANAN: PERIKANAN RUMPON}

Usaha penangkapan ikan nelayan Kedonganan sebagaimana diacu dalam penelitian ini dilakukan menggunakan rumpon ${ }^{2}$. Nelayan rumpon yang menangkap ikan pada umumnya didatangkan dari Sulawesi oleh pemilik modal di Kedonganan. Hal ini didorong oleh kenyataan bahwa nelayannelayan tersebut memiliki pengalaman menangkap ikan menggunakan rumpon. Rumpon merupakan sebuah nilai tambah yang diakui oleh para pemilik modal, yang adalah warga setempat. Pemilik modal di Kedonganan mencari pihak yang dianggap mampu dalam hal penangkapan ikan dengan berkunjung secara langsung ke Sulawesi. Proses pencarian rekanan kerjasama seperti

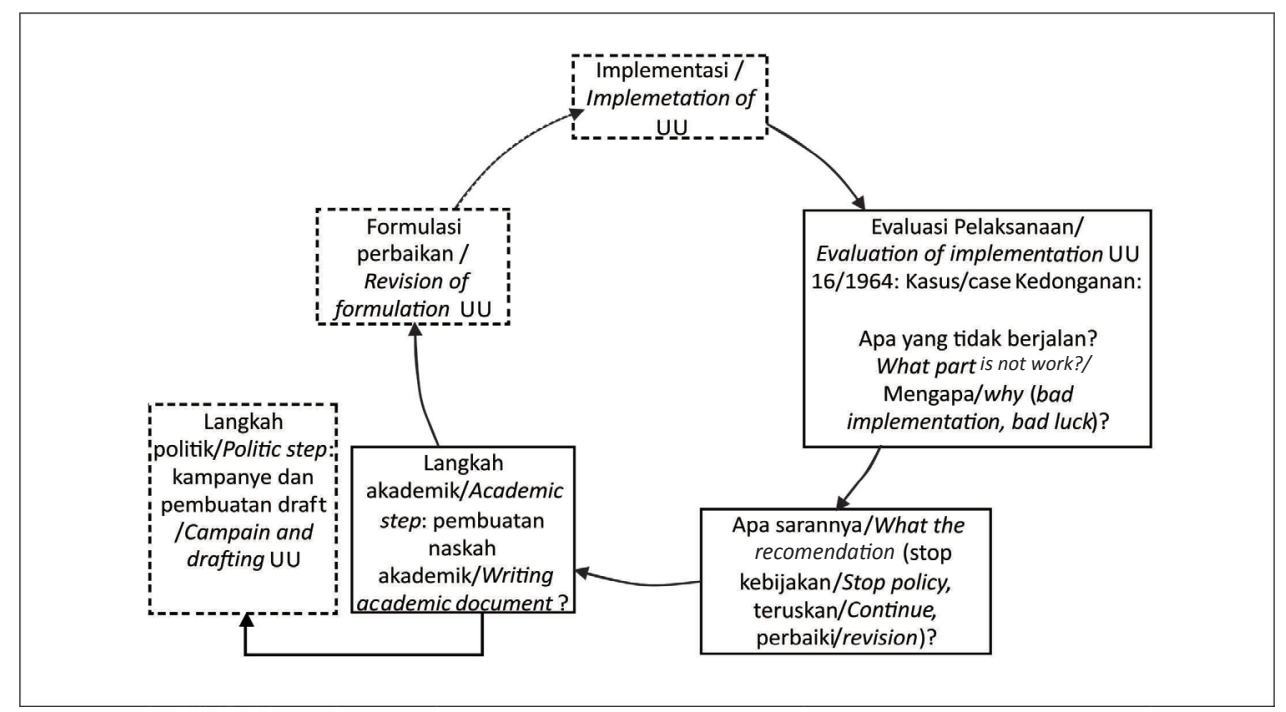

Gambar 1. Kerangka Konseptual Penelitian

Figure 1. Conseptual Research Framework

Keterangan: Panah dan kotak bergaris penuh adalah domain peneliti

Remarks: Bullet and narrow is domain of the reasercher

\footnotetext{
${ }^{2}$ Rumpon adalah sebuah bangunan yang menyerupai pepohonan yang digunakan untuk mendapatkan atau mengumpulkan kawanan ikan sebelum dilakukan penangkapan dan diletakkan disuatu tempat ditengah laut (Subani,W dan Baarus, 1989).
} 
itu didasarkan informasi dari nelayan lain yang telah melakukan perjanjian. Penentuan pihak dalam melakukan kerjasama didasari oleh beberapa kriteria, yaitu memiliki kapal dan memiliki $A B K$ yang berpengalaman. Satu unit kapal terdiri 6 ABK (termasuk nahkoda kapal). Jika terjadi kecocokan antara kedua belah pihak, maka selanjutnya sebuah perjanjian kerjasama akan mereka sepakati. Perjanjian tetap dilakukan selama menguntungkan kedua belah pihak. Juragan Sulawesi menyediakan kapal beserta $A B K$, sedangkan pemilik modal (juragan darat) di Kedonganan menyediakan permodalan dalam melakukan penangkapan beserta peralatan yang digunakan dalam kegiatan penangkapan. Modal awal yang diberikan kepada Juragan Sulawesi adalah sebesar 5-7 juta dan diperuntukkan bagi pembelian solar untuk perjalanan menuju Kedonganan serta untuk pengadaan peralatan pancing (Muhartono et al., 2007)

\section{PELAKSANAAN PENERAPAN UU BAGI HASIL}

\section{Ketidaksesuaian dalam Hal Pengaturan Proporsi}

Mekanisme bagi hasil di Kedonganan menunjukkan ketidaksesuaian dari UU yang ada, dan cenderung lebih dikaitkan dengan karakteristik budaya dan adat istiadat setempat, jenis alat tangkap dan kebijakan pemilik modal. Perbedaan tersebut dapat dilihat pada Gambar 2 dan 3. Di Kedonganan, bagian yang didistribusikan kepada para nelayan adalah penerimaan yang sebelumnya telah dipotong untuk biaya operasional. Hal ini berbeda dengan pasal 3 (UUBH No.16 Tahun 1964), yang menyatakan bahwa pada perikanan laut, jika penangkapan dilakukan menggunakan kapal motor, seperti halnya pada kasus dalam penelitian ini, maka proporsi yang diberikan kepada penangkap sebesar $40 \%$ dari hasil bersih.

Pada Gambar 3. terlihat bahwa setiap hasil tangkapan yang didapat nelayan dipotong dengan biaya operasional. Biaya tersebut adalah biaya untuk membeli ransum selama di laut seperti makanan, bbm dll.
Biaya iuran sebesar 3\% yang dipotong dari jumlah tangkapan dan uang makan (jan-coan) juga diberlakukan. Besarnya uang jan-coan bervariasi Rp 400.000-600.000 tergantung hasil tangkapan yang didapat dan kebijaksanaan pemodal. Uang jan-coan diberikan kepada nelayan penggarap ( $A B K$ ) setiap melaksanakan bongkar muatan kapal. Pembagian untuk juragan laut (nakhoda) sebesar 2 bagian dan untuk 5 orang $A B K$, masing-masing mendapatkan 1 bagian.

Sementara itu, menurut mekanisme bagi hasil yang mengacu pada UUBH No.16 tahun 1964 menggunakan Kapal motor (Gambar 2), seharusnya seluruh hasil tangkapan ikan dikurangi oleh biaya lawuhan yang biasanya ditentukan oleh kebiasaan adat setempat dan dikurangi oleh biaya yang menjadi tanggungan bersama antara nelayan pemodal dan nelayan penggarap. Hasil bersih tangkapan dibagi menjadi 2 bagian, pertama $60 \%$ yang diberikan kepada pemilik dan bagian kedua sebesar $40 \%$ diberikan kepada penggarap (ABK). Untuk mendapatkan pendapatan bersih pemilik, maka $60 \%$ bagian tersebut harus dikurangi dengan biaya yang menjadi tanggungan pemilik. Sementara itu, pendapatan bersih penggarap/ABK dibagi sesuai proporsi yang berlaku di daerah masingmasing.

\section{Ketiadaan Beban Tanggungan}

Penyimpangan lain terjadi pada Pasal 4 ayat 1.a., yang menyebutkan bahwa pada usaha perikanan laut terdapat beban-beban yang menjadi tanggungan bersama antara nelayan pemilik dan penggarap, yaitu: ongkos lelang, uang rokok atau jajan dan biaya perbekalan untuk para nelayan penggarap selama dilaut, biaya sedekah laut (selamatan bersama) serta iuran-iuran yang disyahkan oleh Pemerintah Daerah Tingkat II seperti koperasi dan pembangunan perahu/kapal, dana kesejahteraan, dana kematian dan lain-lain. Selain itu pada pasal yang sama ayat 1.b menyatakan terdapat beban-bedan yang menjadi tanggungan nelayan pemilik yaitu ongkos pemeliharaan dan perbaikan perahu/kapal serta alat-alat lain yang 


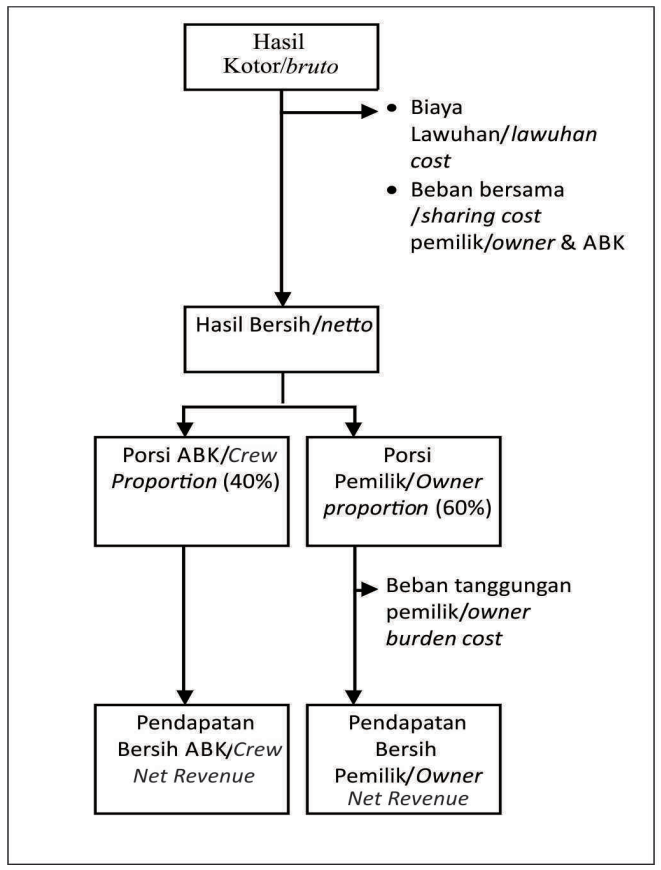

\section{Gambar 2. Sistem Bagi Hasil Menurut UU 16/1964. \\ Figure 2. Sharing System Based on UU 16/1964.}

digunakan, penyusutan dan biaya eksploitasi usaha penangkapan seperti untuk pembelian solar, minyak, es dan lain-lain.

Untuk kasus bagi hasil di Kedonganan, biaya tanggungan yang dibebankan pada nelayan pemilik (juragan darat), penggarap (ABK) maupun tanggungan bersama tidak ada. Seluruh biaya yang dikeluarkan untuk biaya operasional nelayan selama mencari ikan (solar, ransum, dll) dibebankan sebagai biaya potongan pada setiap perhitungan bagi hasil. Dalam hal ini seluruh biaya yang dikeluarkan menjadi biaya operasional dan dibebankan dalam usaha. Jika dalam sebuah perhitungan terjadi kerugian, yaitu saat hasil tangkapan lebih sedikit dibandingkan pengeluaran, maka kerugian ini akan menjadi sebuah hutang yang akan dihitung pada saat bagi hasil selanjutnya.

Disatu sisi, nelayan penggarap (ABK) menyatakan bahwa pembebanan biaya secara bersama dipandang sebagai sesuatu

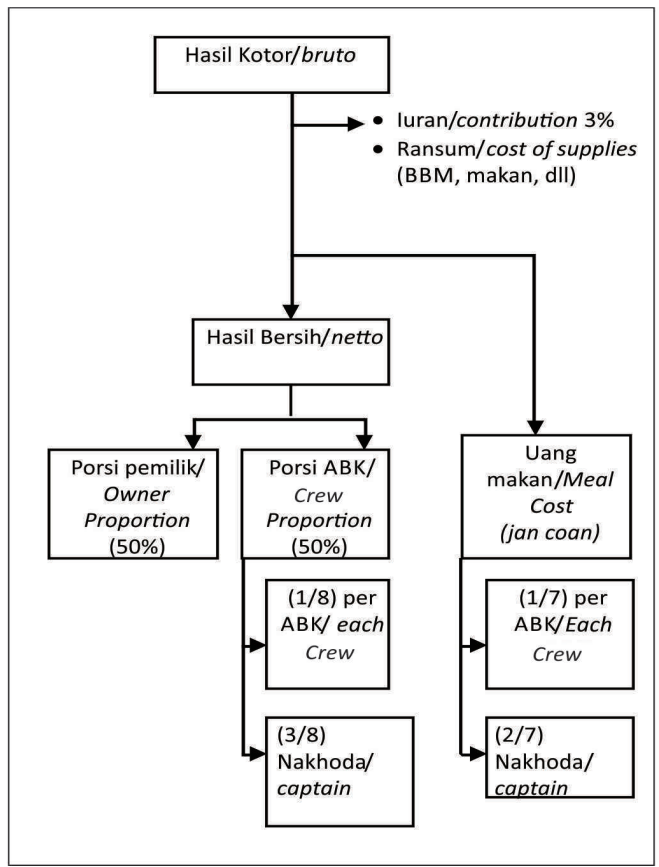

\section{Gambar 3. Sistem Bagi Hasil Perikanan Rumpon di Kedonganan/ \\ Figure 3. Rumpon Sharing System at Kedonganan}

memberatkan. Hal ini dikarenakan nelayan penggarap (ABK) memiliki keterbatasan dalam kepemilikan modal/kapital. Disatu sisi, nelayan penggarap ( $A B K$ ) telah memberikan sumbangan terbesar dalam usaha penangkapan berupa keahlian, curahan waktu dan adanya resiko kematian pada saat melakukan penangkapan. Di sisi lain, nelayan pemilik tidak menyetujui adanya biaya tanggungan pemilik karena memiliki kekhawatiran akan mengalami kerugian jika harus menanggung biaya pembelian solar, es, pemeliharaan dan eksploitasi. Alasannya, usaha perikanan tangkap memiliki resiko tinggi atas ketidakpastian terhadap jumlah hasil tangkapan yang akan didapat.

\section{Jangka Waktu Perjanjian}

Pada pasal 7 ayat 1 UUBH No.16 Tahun 1964 disebutkan bahwa perjanjian bagi hasil diadakan untuk waktu paling sedikit 2 musim 
yaitu 1 tahun berturut-turut bagi perikanan laut. Ayat 2 menyatakan bahwa perjanjian bagi hasil tidak terputus karena pemindahan hak atas perahu /kapal. Alat-alat penangkap ikan atau tambak yang bersangkutan kepada orang lain. Di dalam hal yang demikian maka semua hak dan kewajiban pemilik yang lama beralih kepada pemilik yang baru. Ayat 3 menyatakan bahwa: "Jika seorang nelayan penggarap atau penggarap tambak meninggal dunia, maka ahli warisnya yang sanggup dan dapat menjadi nelayan penggarap tambak dan mengendakinya, berhak untuk melanjutkan perjanjian bagi hasil yang bersangkutan, dengan hak dan kewajiban yang sama hingga jangka waktunya berakhir".

Jangka waktu perjanjian bagi hasil di Kedonganan dibuat berdasarkan kesepakatan bahwa usaha yang dilakukan masih menguntungkan dan tidak didasari pada jumlah musim tangkap. Jika usaha masih menguntungkan maka kesepatan tersebut tetap akan berjalan. Namun, jika mengalami kerugian yang kelanjutan, kesepakatan dapat diberhentikan secara sepihak oleh pemilik modal. Perjanjian ini dilakukan antara juragan sulawesi sebagai pemilik kapal dengan juragan darat (Bali) sebagai pemilik modal. Jika terjadi kasus nelayan penggarap ( $A B K$ ) meninggal dunia, maka dengan sendirinya perjanjian bagi hasil antara pihak nelayan penggarap dan pemilik modal menjadi terhenti dan perjanjian diteruskan dengan menerima tenaga baru dan tidak harus berasal dari ahli waris nelayan tersebut. Sebagai catatan, kasus perpindahan kepemilikan hak atas perahu/ kapal tidak ditemukan di Kedonganan.

\section{KENDALA PENERAPAN UUBH NO 16 TAHUN 1964}

\section{Ketidaksesuaian dengan Adat Istiadat Setempat}

Untuk kasus di Kedonganan, masyarakat lebih memilih menerapkan bagi hasil menurut adat setempat dibandingkan mengikuti UUBH No.16 Tahun 1964. Hal ini dikarenakan faktor kebiasaan dalam melakukan bagi hasil yang sudah berlangsung lama. Oleh masyarakat, kebiasaan setempat yang sudah berlaku lama tersebut lebih dapat diterima dibanding halhal yang terkandung dalam UU 16/1964. Hal ini dapat dikaitkan dengan sinyelemen Murtadi dalam Ratna (1999), yang menyatakan bahwa hukum tidak berfungsi sebagai alat untuk merubah masyarakat, karena undangundang tersebut tidak sesuai dengan nilai-nilai sosial budaya masyarakat setempat, sehingga dorongan untuk melaksanakan peraturanperaturan sesuai dengan hukum tersebut tidak ada. Implikasi dari fenomena seperti itu adalah bahwa UU tersebut seharusnya lebih menyesuaikan dengan kondisi setempat. Bentuk penyesuaian tersebut adalah misalnya dalam hal pencantuman klausul yang memungkinkan adanya modifikasi terbatas, yang dikaitkan dengan keadaan lokal.

\section{Keterbatasan Informasi}

Seluruh reponden nelayan menyatakan tidak mengetahui isi peraturan UUBH no 16 Tahun 1964. Beberapa hal yang menjadi alasannya adalah antara lain; UndangUndang ini telah berlangsung lama dan tidak ada sosialisasi lanjutan sehingga informasi tentang Undang-undang ini menjadi terbatas dan tidak menjangkau nelayan. Ketidaktahuan itu menyebabkan nelayan berpandangan bahwa mekanisme bagi hasil yang selama ini dilakukan merupakan sesuatu yang harus dilaksanakan dan pantang untuk dilakukan perubahan.

\section{Tidak ada ruang / Pilihan dan Kewenangan untuk Merubahnya}

Keterbatasan dalam tingkat pendidikan, sulitnya mencari pekerjaan di luar sektor perikanan dan tidak adanya keahlian lain membuat nelayan menjadi pihak yang tidak dapat berbuat banyak terhadap kondisi yang ada. Mereka berfikir bahwa sudah tidak ada pilihan pekerjaan lain selain pekerjaan menjadi seorang ABK. Kesadaran akan kondisi seperti ini membuat mereka selalu menjadi pihak yang menerima. Selain itu nelayan penggarap (ABK) tidak memiliki posisi tawar yang tinggi untuk mengajukan perubahan terhadap proporsi 
bagi hasil yang ada. Menurut Satria (2002) desakan kebutuhan ekonomi dan uang tunai yang tinggi dan muncul setiap hari memaksa nelayan tidak bisa melakukan spekulasi untuk mendapatkan harga yang ditawarkan (price taker) dan menjalankan hidupnya dari hari ke hari dengan uang tunai yang didapatkannya. Selama ini yang terjadi adalah posisi tawar (bargaining possition) nelayan pekerja $(A B K)$ dihadapan pemilik/pemodal rendah. Nelayan pekerja (ABK) tidak memiliki kemampuan untuk melakukan perubahan terhadap peraturan bagi hasil yang selama ini berlaku dan selalu menjadi pihak yang selalu menerima terhadap setiap keputusan juragan dalam melakukan kesepakatan (Muhartono, 2004).

\section{Ketiadaan Lembaga Kontrol Yang Secara Efektif Mengawal Implementasi UUBH No 16 Tahun 1964}

Untuk menjamin pelaksanaan bagi hasil tidak merugikan nelayan penggarap (ABK) di setiap lokasi maka diperlukan sebuah lembaga yang berfungsi sebagai kontrol dalam pelaksanaan UU tersebut. Lembaga ini dapat berupa pemberian wewenang tambahan kepada lembaga yang sudah ada seperti Dinas Perikanan setempat. Dengan demikian jika ditemukan permasalahan yang membutuhkan penanganan secepatnya dapat dilakukan tindakan yang dapat menyelesaikan permasalahan dengan tepat dan tidak berlarut-larut yang dapat merugikan kedua belah pihak.

\section{PERMASALAHAN DAN URGENSI PERBAIKAN UNDANG-UNDANG}

Berbagai permasalahan tersebut di atas, yang menyebabkan tidak optimalnya UUBH No 16/1964, secara diagramatis dapat dirangkum sebagaimana terlihat pada Gambar 4. Sebagian permasalahan tersebut dapat dikategorikan sebagai masalah substantif, yaitu permasalahan yang betulbetul perlu mendapatkan perhatian apabila Undang-undang tersebut harus dijalankan. Dari sejumlah masalah substantif tersebut,

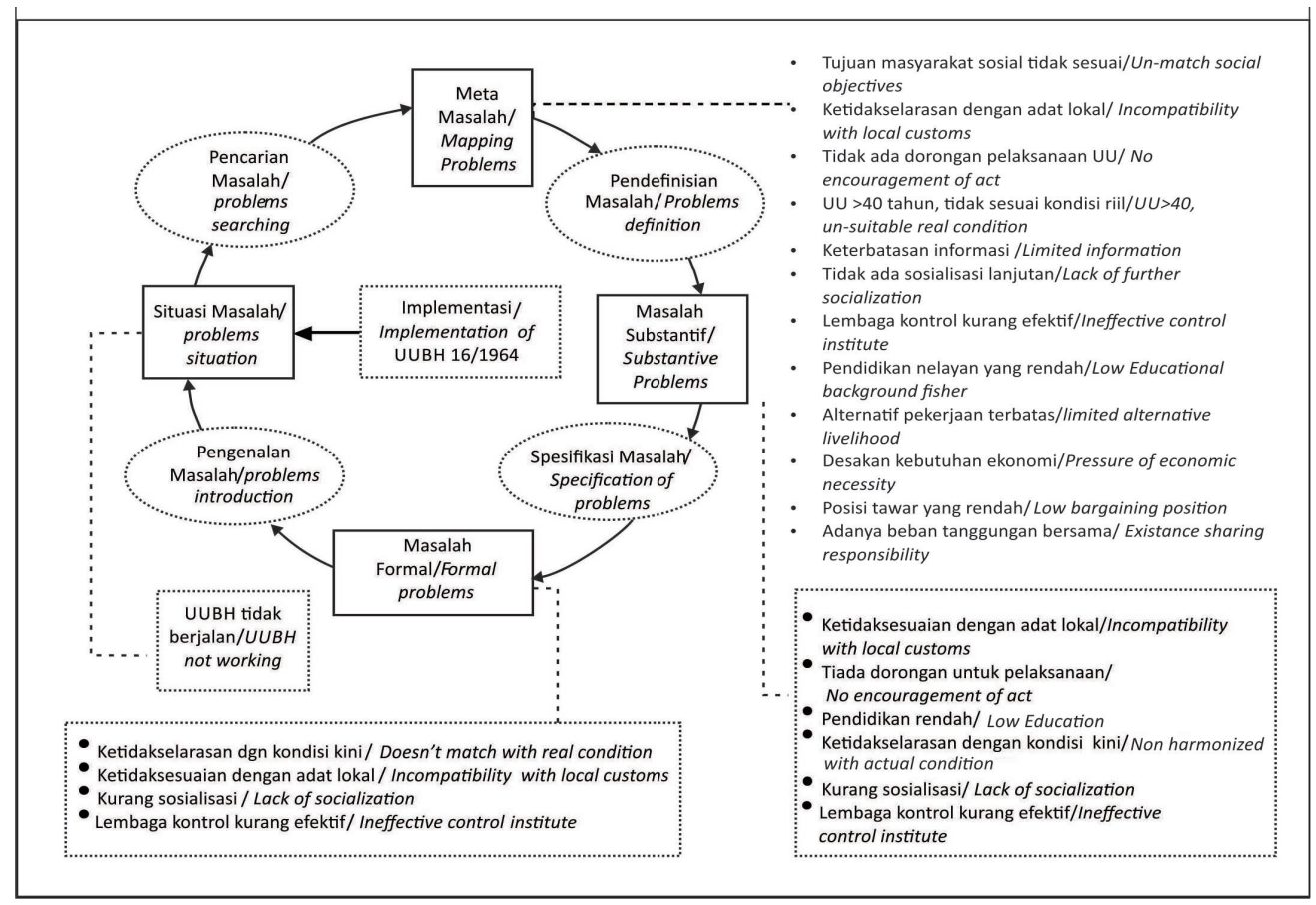

Gambar 4. Sintesa Permasalahan/

Figure 4. Problems Synthesis 
sebagian di antaranya merupakan masalahmasalah formal, yang dapat dipecahkan melalui penerapan kebijakan tertentu, termasuk kebijakan yang dituangkan kedalam Undangundang atau perbaikan Undang-undang.

Berdasarkan sintesa permasalahan seperti termuat pada Gambar 4, setidaknya terdapat 4 (empat) masalah formal yaitu:

- Ketidakselarasan UUBH 16 /1964 dengan kondisi saat ini;

- Ketidaksesuaian UU tersebut dengan dengan adat lokal;

- Kurang sosialisasi tentang UU tersebut, dan;

- Ketiadaan lembaga kontrol yang secara efektif mengawal pelaksanaan UU tersebut.

Karenanya, keempat masalah formal tersebut harus dipandang sebagai aspekaspek yang perlu segera ditindaklanjuti dengan langkah berikutnya, yaitu pembuatan kebijakan-kebijakan yang relevan.

\section{PENUTUP}

Berdasarkan hasil penelitian diperoleh kesimpulan bahwa teridentifikasi adanya ketidaksesuaian penerapan UU di lapangan, antara lain dalam hal besaran proporsi, beban tanggungan, dan jangka waktu perjanjian. Kelemahan yang menyebabkan penyimpangan tersebut terjadi baik pada aspek materi maupun implementasi. Pada aspek materi, ditemukan bahwa produk hukum tersebut tidak selaras dengan kondisi lokal, termasuk adat setempat. Sementara itu, pada aspek implementasi, produk hukum tersebut tidak berjalan baik karena keterbatasan informasi, ketiadaan ruang untuk modifikasi, dan ketiadaan lembaga kontrol yang secara efektif mengawal pelaksanaannya.

Berdasarkan hasil kajian direkomendasikan hal-hal antara lain: beberapa pasal UU 16/1964 sebaiknya disempurnakan, yaitu yang menyangkut bagian pemilik modal, biaya penyusutan aset, dan umur ekonomis aset produksi dalam perhitungan bagi hasil. Kemudian perlu diberikan mandat khusus kepada sebuah lembaga untuk melakukan pengawalan terhadap implementasi UU sehingga efektivitas UU dapat ditingkatkan. Akhirnya, perlu disusun sebuah naskah akademis yang dikembangkan berdasarkan perluasan cakupan kajian ini, yang digunakan untuk mendorong penyempurnaan UU, sehingga selaras dengan kondisi saat ini, demi perkembangan perikanan yang lebih baik.

\section{DAFTAR PUSTAKA}

Balai Besar Riset Sosial Ekonomi Kelautan dan Perikanan. 2006. Indikator Kinerja Sektor Kelautan dan Perikanan Edisi Revisi dan Updating. Volume II: Sarana Teknologi, Sumber Daya Manusia dan Pengembangan/Investasi Sektor Kelautan dan Perikanan. Balai Besar Riset Sosial Ekonomi Kelautan dan Perikanan. Jakarta.

Herwening, E. 1983. Bagi hasil Usaha Penangkapan Ikan (Kasus Muara Angke, Jakarta).Skripsi. Fakultas Perikanan. Institut Pertanian Bogor. Bogor;

Muhartono, R. 2004. Alternatif Pola Bagi Hasil Nelayan Gillnet di Muara Baru, Jakarta Utara. Skripsi. Jurusan Sosial Ekonomi Perikanan. Institut Pertanian Bogor. Bogor.

Muhartono, R., A.Zamroni dan E. Reswati. 2007. Pola Bagi Hasil Nelayan Rumpon Di Kedonganan, Kabupaten Badung, Warta Sosial Ekonomi. Balai Besar Riset Sosial Ekonomi Kelautan dan Perikanan.

Mustopadidjaja. AR., 2003. Manajemen Proses Kebijakan Publik (Formulasi, Implementasi dan Evaluasi). Lembaga Administrasi Negara. Duta Pertiwi Foundation. Jakarta

Nazir, M. 1998. Metode Penelitian. Ghalia Indonesia. Jakarta. 622 hal 
Ratna, P.M. 1999. Suatu Tinjauan Terhadap Sistem Bagi Hasil Perikanan Laut di Pusat Pendaratan Ikan Bajomulyo Kecamatan Juwana, Kabupaten Pati Propinsi Jawa Tengah. Skripsi. Fakultas Perikanan dan Ilmu Kelautan.Institut Pertanian Bogor. Bogor.

Satria, A.2002. Pengantar Sosiologi Masyarakat Pesisir. Cidesindo. Jakarta.

Singarimbun, M., dan S. Effendi. 1985. Metode Penelitian Survey. LP3S. Jakarta. 192 hal
Subani, W. dan Baarus, H.R. 1989. Alat Penangkapan Ikan dan Udang Laut di Indonesia. Jurnal Penelitian Perikanan Laut. Balai Penelitian Perikanan Laut. Badan Penelitian dan Pengembangan Pertanian. Departemen Pertanian. Jakarta.

Undang-Undang Bagi Hasil No.16 Tahun 1964. Tentang : Bagi Hasil Perikanan. Lembaran Negara RI No. 2690 Sekretaris Negara. Jakarta. 